\title{
PENINGKATAN PRODUKTIVITAS MELALUI DIGITALISASI PADA UKM FORTUNA HANDYCRAFT DALAM MENGHADAPI LESS CONTACT ECONOMY
}

\author{
Ni Putu Cempaka Dharmadewi Atmaja, Ary Wira Andika, Krisna Kurniari, \\ I Gusti Ayu Asri Pramesti \\ Universitas Mahasaraswati Denpasar \\ Jalan Kamboja No.11A, Dangin Puri Kangin, Denpasar Utara, Denpasar - 80233 \\ cempakaharry@gmail.com
}

\begin{abstract}
The seaweed waste craft has been pursued for almost 10 years by UKM Fortuna Handycraf whose products have been exported to various countries in Continental Europe and America. However, during the pandemic, SMEs had difficulty in increasing productivity due to various constraints such as production technology, marketing and managerial capacity constraints. UKM Indonesia Bangkit program provides a solution to solve the problem, namely the solution of technological capacity constraints by procuring production machines such as cutting machines, seat drilling machines, compressors, work desks and wheelbarrows. Marketing / distribution and managerial constraint solutions with the design and manufacture of Android-based Management Information System (SIMBA) that can help partners use communication and database-based information technology to provide partner knowledge and expertise to conduct marketing activities (product updates, online sales, online transactions, distribution arrangements), inventory activities (inventory arrangements are based on online purchase orders), and assist in the preparation of company profit and loss reports. In addition, it also offers marketing media using neon box boards. The solution provided can help increase the productivity of FortunaHandycraft SMEs in terms of production, digital marketing and managerial.
\end{abstract}

Keywords: SME digitization, precise technology, SIMBA

\begin{abstract}
Abstrak
Kerajinan limbah kayu laut sudah ditekuni hampir 10 tahun oleh UKM Fortuna Handycraf yang produknya sudah dieksport ke berbagai negara di Benua Eropa dan Amerika. Akan tetapi pada masa pandemi, UKM kesulitan untuk meningkatkan produktivitas karena berbagai kendala seperti kendala kapasitas teknologi produksi, pemasaran dan manajerial. Program UKM Indonesia Bangkit memberikan solusi untuk mengatasi permasalahan itu yaitu solusi kendala kapasitas teknologi dengan pengadaan mesin-mesin produksi seperti mesin potong, mesin bor duduk, mesin kompresor, meja kerja dan gerobak sorong. Solusi kendala pemasaran/distribusi dan manajerial dengan perancangan dan pembuatan Sistem Informasi Manajemen berbasis Android (SIMBA) yang dapat membantu mitra menggunakan teknologi komunikasi dan informasi berbasis database sehingga dapat memberikan pengetahuan dan keahlian mitra untuk melakukan kegiatan pemasaran (update produk, penjualan online, transaksi online, pengaturan distribusi), kegiatan persediaan (pengaturan persediaan didasarkan dari online purchase order), dan membantu pembuatan laporan laba rugi perusahaan. Selain itu juga menawarkan media pemasaran dengan menggunakan papan neon box. Solusi yang diberikan dapat membantu peningkatan produktivitas UKM FortunaHandycraft dari segi produksi, pemasaran digital dan manajerial.
\end{abstract}

Kata kunci: digitalisasi UKM, teknologi tepat guna, SIMBA

\section{Pendahuluan}

Terpuruknya industri pariwisata di Bali akibat pandemi Virus Corona (Covid-19) memberikan dampak bagi industri kerajinan di Bali, salah satunya adalah UKM Fortuna Handycraft. UKM ini membuat dan menjual kerajinan dari kayu limbah laut. Industri kerajinan saat ini sangat membutuhkan pengetahuan dan teknologi yang dapat meningkatkan peluang untuk meraih pasar yang lebih besar melalui digitalisasi pemasaran dan ekonomi untuk menghadapi era less contact economy.
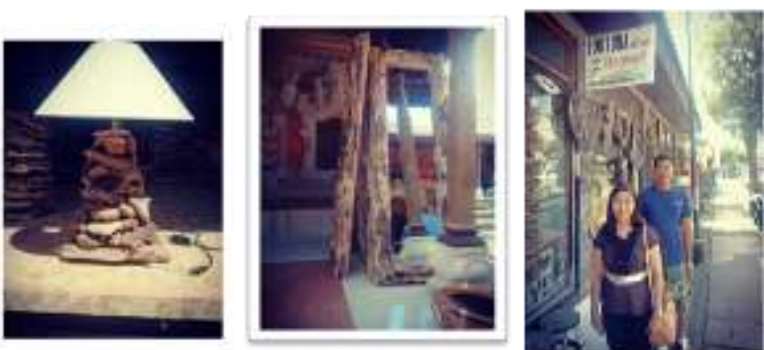

Gambar 1 
Jenis produk olahan Kayu Limbah Laut dan Art shop Fortuna Handycraft

Fortuna Handycraft memanfaatkan limbah kayu untuk membuat kerajinan seni seperti lampu hias, cermin hias, kepala buffalo dan lain sebagainya. Usaha ini sudah berjalan sejak tahun 2010 sampai sekarang. Produk UKM ini angat diminati oleh pasar Eropa dan Amerika, sehingga sering melakukan kegiatan eksport ke negara-negara tersebut seperti ke Italia, Belanda, Inggris dan USA.

Peningkatan produktivitas sangat diperlukan dalam meningkatkan daya saing UKM di tingkat internasional. Menurut Sinungan (2014:17) mengemukakan bahwa Produktivitas adalah suatu konsep yang bersifat universal yang bertujuan untuk menyediakan lebih banyak barang dan jasa yang akan digunakan oleh banyak manusia, dengan menggunakan sumbersumber riil yang semakin sedikit.Menurut Sutrisno (2011:104), indikator yang mencerminkan produktivitas adalah hasil capaian. Semakin tinggi hasil capaian produksi, maka akan semakin tinggi pula produktivitas. Tetapi dalam mencapai produktivitas yang tinggi,

UKM mempunyai permasalahan dalam usahanya. Hasil observasi menunjukan bahwa mitra mempunyai 3 permasalahan utama dalam meningkatkan produktivitas pada era less contact economy yaitu dari aspek peningkatan kapasitas teknologi, aspek teknologi pemasaran, dan aspek manajerial. Dilihat dari aspek kapasitas teknologi, mitra mempunyai alat-alat produksi yang sudah usang dan tidak sesuai dengan kebutuhan produksi. Dilihat dari aspek pemasaran yaitu mitra belum mampu memasarkan produk secara aktif dan luas karena media komunikasi dan informasi yang terbatas. Hal ini menyebabkan saat ini mitra belum mampu menghadapi tuntutan less contact economy dalam meningkatkan produktivitasnya. Dari sisi manajerial, mitra kesulitan untuk mengatur persediaan dan keuangan perusahaan.

Untuk dapat mengatasi permasalahan tersebut terutama permasalahan manajerial seperti pemasaran dan pembukuan maka penetrasi teknologi informasi dan komunikasi sangat diperlukan oleh UKM. Pada era pandemi, maka kontak langsung antara produsen dengan konsumen akan dibatasi sehingga dibutuhkan teknologi informasi dan komunikasi (TIK) berdasarkan database. Adanya penguasaan TIK berbasis database oleh UKM diharapkan dapat meningkatkan kemampuan dalam pengelolaan manajemen dan dapat meningkatkan kemampuan pemasaran di era digital.

Sutabri (2014:3) menyatakan bahwa teknologi informasi adalah suatu teknologi yang digunakan untuk mengolah data, termasuk memproses, mendapatkan, menyusun, menyimpan, memanipulasi data dalam berbagai cara untuk menghasilkan informasi yang berkualitas, yaitu informasi yang relevan, akurat dan tepat waktu, yang digunakan keperluan pribadi, bisnis, dan pemerintahandan merupakan informasi yang strategis untuk pengambilan keputusan. Mulyadi (2014:21) menyatakan bahwa "Teknologi informasi adalah mencakup komputer (baik perangkat keras dan perangkat lunak), berbagai peralatan kantor elektronik, perlengkapan pabrik dan telekomunikasi. Susanto (2013:72) menyatakan bahwa database merupakan kumpulan data-data yang tersimpan di dalam media penyimpanan di suatu perusahaan (arti luas) atau di dalam komputer (arti sempit).

TIK dapat mendukung peran Sistem Infromasi Manajemen (SIM) dalam suatu perusahaan. Jogiyanto (2005:14) menyatakan bahwa sistem informasi manajemen (management information systems) merupakan penerapan sistem informasi di dalam organisasi untuk mendukung informasi-informasi yang dibutuhkan oleh semua tingkatan manajemen. Sistem Informasi Manajemen dapat mengintegrasikan kegiatankegiatan manajerial seperti kegiatan pembelian persediaan, kegiatan penjualan, kegiatan pemasaran dan pencatatan keuangan sangat diperlukan oleh UKM dalam meningkatkan kinerjanya. Sistem informasi manajemen melalui penguasaan teknologi informasi diharapkan mampu meningkatkan kemampuan manajerial UKM sehingga diharapkan mampu memenangkan persaingan di era less contact economy dan era digital.

\section{Metode Pelaksanaan}

Program UKM Indonesia Bangkit memberikan peluang untuk mengatasi permasalahan mitra. Adapun metode pelaksanaan yang dilakukan adalah:

1. Metode dalam peningkatan kapasitas teknologi adalah : melakukan survei untuk pembelian alat-alat yang dibutuhkan untuk keperluan produksi, melakukan pembelian dan pengadaan alat-alat yang diperlukan untuk produksi, penyerahan alat-alat produksi kepada mitra yaitu mesin potong, mesin bor duduk, kompresor, meja kerja dan gerobak, melakukan penilaian dan perbandingan terhadap kinerja mesin yang lama dan yang baru.

2. Metode pelaksanaan peningkatan teknologi pemasaran dan manajerial: perancangan SIMBA (Sistem Informasi Manajemen Berbasis Android), perancangan dan pengadaan Neon Box, perancangan dan pengerjaan kanopi.

Perancangan dan pembuatan Sistem Informasi Manajemen berbasis Android (SIMBA) yang dapat membantu mitra 
menggunakan teknologi komunikasi dan informasi berbasis database sehingga dapat memberikan pengetahuan dan keahlian mitra untuk melakukan kegiatan pemasaran (update produk, penjualan online, transaksi online, pengaturan distribusi), kegiatan persediaan (pengaturan persediaan didasarkan dari online purchase order), dan membantu pembuatan laporan laba rugi perusahaan.

$\begin{array}{lcr}\text { "SIMBA" } & \text { (Sistem } & \text { Informasi Manajemen } \\ \text { Berbasis } & \text { Android) } & \text { merupakan }\end{array}$ aplication yang menggunakan database clouding yang terdapat pada server hosting. Mobile aplication ini menggunakan MySQL database yang terdaftar pada hosting. SIMBA sangat bermanfaat bagi Mitra untuk mengembangkan produktivitasnya dalam aspek pemasaran dan manajerial. Dalam aspek pemasaran, Mitra melalui aplikasi SIMBA dapat melakukan pemasaran secara aktif dengan secara berkesinambungan memberikan informasi mengenai produk-produk terkini dan melakukan penjualan. Mitra dapat mengundang konsumen atau calon konsumennya untuk menggunakan/ mengunduh aplikasi tersebut melalui media sosial (Facebook, istagram, twitter, dan lain-lain) sehingga konsumen yang sudah mengunduh aplikasi tersebut dapat berkomunikasi secara aktif dengan mitra dan dapat melakukan pemesanan melalui aplikasi tersebut. SIMBA juga menggunakan fasilitas Fire base untuk memberikan notifkasi kepada konsumen jika pembayaran sudah diterima oleh mitrasecara online dan konsumen juga dapat mengetahui proses pengiriman barang dan penerimaan barang.

Dari sisi manajerial, aplikasi SIMBA dapat membantu mitra dalam melakukan online purchase order dan mendapatkan online purchse kepada supplier sehingga secara otomatis barang yang diterima akan dimasukan sebagai stok. SIMBA dapat membantu Mitra mengetahui kebutuhan persediaan secara optimal. Selain itu SIMBA juga dapat melakukan analisa biaya sehingga mitra mendapatkan luaran berupa laporan laba rugi.

\section{Keluaran yang dicapai (Output) Pelaksanaan peningkatan kapasitas teknologi produksi}

Keluaran yang dicapai pada Program Kemitraan Masyarakat adalah sudah memberikan beberapa alat produksi. Peralatan yang dipakai untuk memproduksi adalah mesin potong, mesin bor, kompresor dan alat tembak paku.

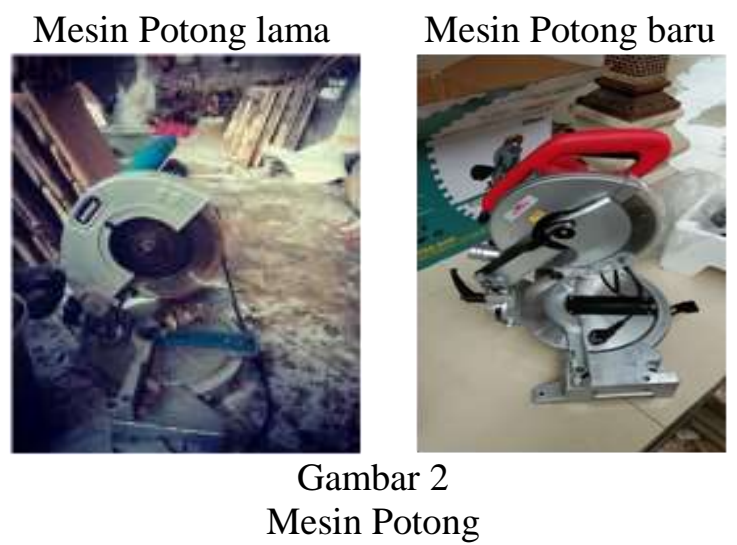

Mesin potong yang baru mempunyai kapasitas pemotongan yang lebih besar sehingga dapat memotong kayu besar sekaligus memotong kayu yang kecil. Hal ini menyebabkan pekerjaan memotong kayu dapat lebih cepat sehingga pekerjaan cepat terselesaikan.

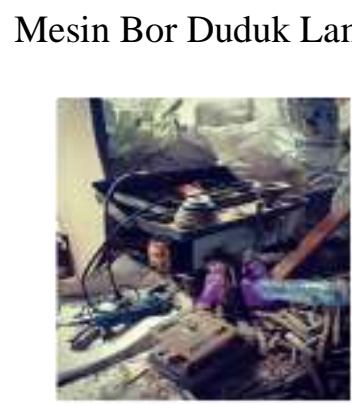

Mesin Bor duduk

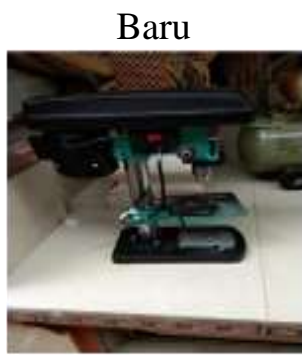

Gambar 3

Mesin Bor Duduk

Mesin bor yang baru dengan mata bor 16 MM membantu mitra untuk melubangi kayu-kayu dengan diameter yang lebih dalam sehingga mempercepat proses produksi.

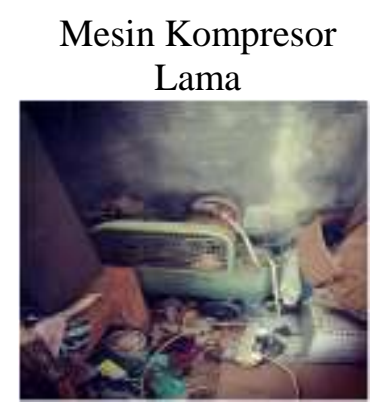

Mesin Kompresor Baru

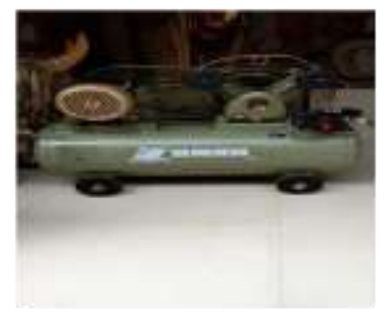

Gambar 4

Mesin Komproser

Kompresor yang baru memberikan tenaga lebih besar (Kapasitas 1 PK) sehingga tenaga paku 
tembak menjadi lebih besar sehingga pekerjaan menjadi lebih cepat selesai.

Gerobak sorong diberikan untuk mempelancar pekerjaan mengangkut bahan-bahan dan juga mengangkut produk ke art shop. Meja kerja digunakan untuk membantu cara kerja karyawan agar lebih baik sehingga tidak menimbulkan masalah fisik di kemudian hari.

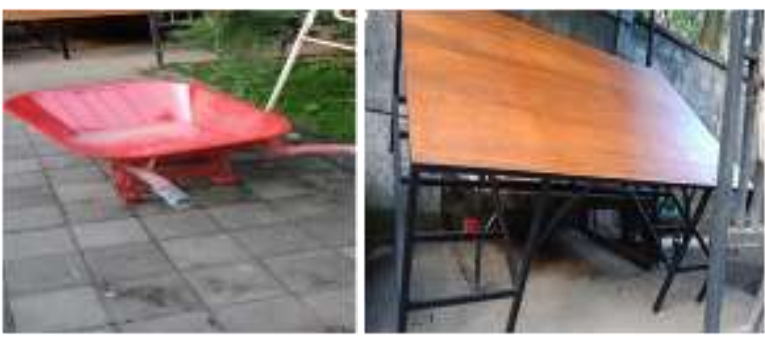

Gambar 5.

Gerobak Sorong dan Meja Kerja

\section{Pelaksanaan pengadaan teknologi pemasaran dan manajerial}

Metode pelaksanaan pengadaan teknologi pemasaran dan manajerial yaiu dengan merancang dan mendesain aplikasi Sistem Informasi Manajemen Berbasis Android (SIMBA) dari sisi pemasaran dan manajerial.
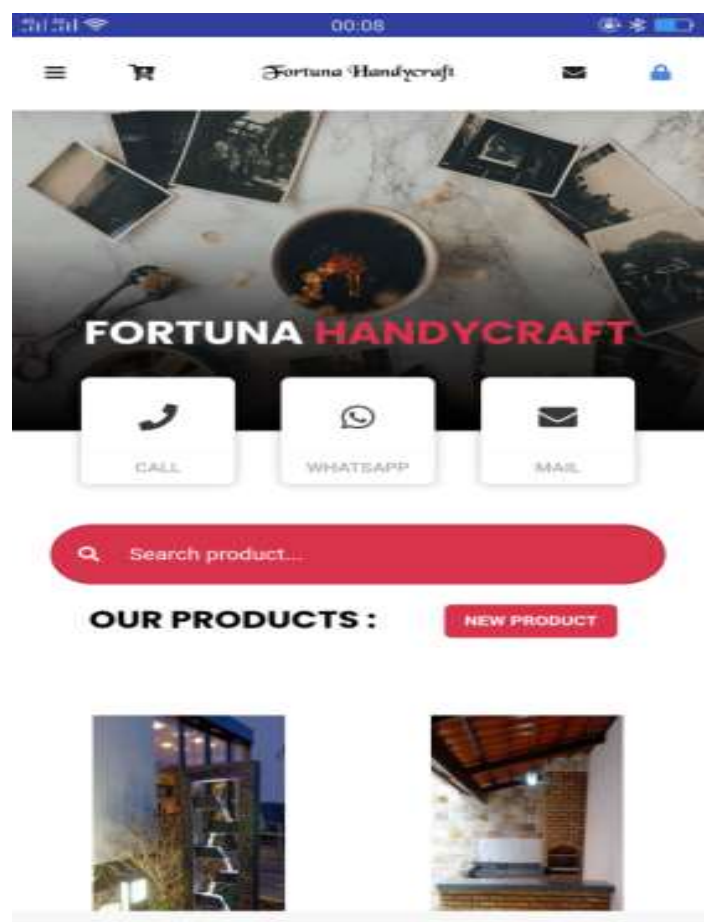

Gambar 6

Tampilan Front Page SIMBA

SIMBA dirancang untuk dapat membantu mitra dalam meningkatkan kemampuan pemasaran dalam platform digital dan manajerial. adapun rancangan SIMBA yang bisa dikontrol dari sisi produsen adalah sebagai berikut. Bagian control panel adalah bagian yang berfungsi sebagai akses untuk mengontrol sistem SIMBA. Adapun tampilan control panen adalah sebagai berikut:
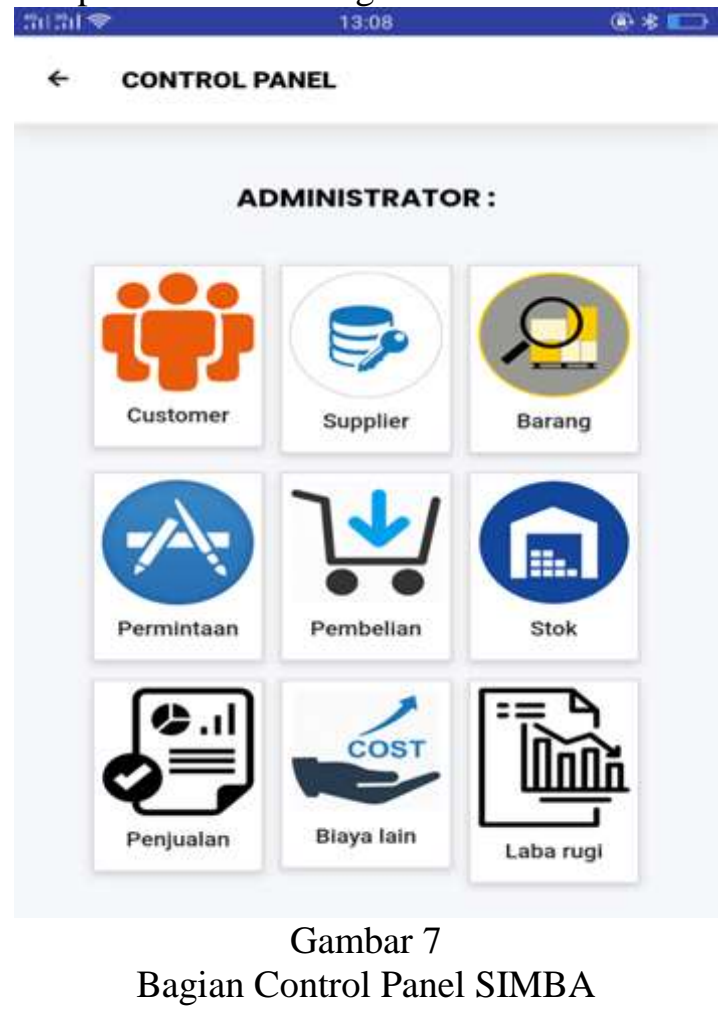

Bagian-bagian cari control panel adalah sebagai berikut:

(1) Customer

Pada bagian ini, merupakan database pelanggan. Mitra dapat mencatat secara rinci mengenai nama pelanggan, no telpon atau alamat, barang yang pernah dipesan dan nota untuk pelanggan.

(2) Supplier

Pada bagian ini mitra dapat mencatat secara rinci mengenai supplier yang memasok bahan baku bagi mitra.

(3) Barang

Pada bagian ini mitra dapat mencatat barangbarang yang sudah diproduksi dan mencatat stok barang jadi yang masih tersedia.

(4) Permintaan

Permintaan akan secara otomatis tercatat apabila ada permintaan dari konsumen yang memesan barang kepada mitra. Permintaan akan ditandai apabila barang sudah jadi dan terkirim.

(5) Pembelian

Pembelian adalah pencatatan terhadap pembelian bahan baku seperti triplek, limbah kayu laut, kaca dan lainnya. Pencatatan pembelian bahan penolong juga dicatat di bagian ini.

(6) Stok 
Stok secara otomatis akan terlihat bila bagian pembelian mencatatat adanya stok dan akan berkurang secara otomatis bila ada dicatat di biaya bahan baku.

(7) Penjualan

Penjualan adalah penjualan yang aktual yang berarti barang sudah dibeli dan menambah pendapatan.

(8) Biaya lain

Biaya adalah biaya yang dicatat oleh mitra sebagai biaya yang dibebankan pada setiap produksi.

(9) Laba rugi

Laba rugi akan secara otomatis terlihat sesuai dengan pendapatan yang tercatat dan biaya yang dicatat oleh mitra.

Mengenai media pemasaran, papan nama yang lama digantikan dengan Neon Box sehingga menjadi lebih menarik. Selain itu Sliding canopy dibuat karena bahan baku yaitu kayu laut rapuh terhadap air hujan tetapi juga membutuhkan panas matahari agar tetap kering, sehingga perencanaan perancangan canopy permanen diubah menjadi sliding canopy. Sliding canopy sangat fleksibel dengan keaadan cuaca. Apabila ada panas matahari maka kanopi bisa dibuka dan bila ada hujan kanopi bisa ditutup.

\section{Manfaat yang diperoleh Mitra}

\section{Peningkatan kapasitas dan produktivitas}

Mesin potong sebelumnya tidak bisa memotong kayu besar dengan satu tahapan saja. Pemotongan dilakukan dengan kapak terlebih dahulu barulah dipotong kecil-kecil dengan kapak. Hal ini menyebabkan waktu pemotongan kayu menjadi lebih lama. Dengan mesin yang baru pemotongan kayu yang besar menjadi lebih cepat karena pemotongan hanya 1 kali saja. Berikut uraian perhitungan waktu memakai mesin lama dan mesin baru:

Tabel 1

\begin{tabular}{|c|c|c|c|}
\hline Kays & Preser & $\begin{array}{l}\text { Minis Luesa } \\
\text { (betik) }\end{array}$ & $\underset{\text { (detia) }}{\min \text { bars }}$ \\
\hline Granter & Penchecul Lepik & 422 & \\
\hline Jan & peratuege pria & 3.34 & 0.97 \\
\hline Jumlat tutal & & 7,50 & an \\
\hline dimaper & 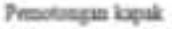 & $1, \pi$ & \\
\hline $\operatorname{sen}$ & penstepep pein & 5.03 & 1.37 \\
\hline Jualat tutal & & 13,31 & 157 \\
\hline fument & Provesega bopak & 34.2 & \\
\hline $7 \mathrm{~cm}$ & penatcage neesin & 0,19 & 3,00 \\
\hline Jemiab tatal & & 4..11 & M.4 \\
\hline marn & & 205 & 18 \\
\hline
\end{tabular}

Sumber: Hasil Observasi, 2020

Dari hasil observasi didapatkan bahwa pemotongan kayu dengan mesin baru lebih cepat daripada pemotongan mesin lama. Mesin lama tidak bisa memotong kayu yang berukurang diameter lebih dari $5 \mathrm{~cm}$ sehingga harus dipotong dengan menggunakan kapak terlebih dahulu. Cara lama ini menghabiskan waktu rata-rata sampai 20,82 detik. Sedangkan dengan menggunakan mesin baru, maka memotong kayu tidak perlu memotong dengan menggunakan kapak lagi sehingga menjadi lebih cepat prosesnya yaitu rata-rata 1,80 detik.

Hal ini menggambarkan produktivitas mesin baru lebih tinggi dibandingkan mesin lama. Perbandingan produktivitas mesin lama dan mesin baru adalah sebagai berikut.

Tabel 2.

Perbandingan Produktivitas Mesin Potong Lama dan Baru

\begin{tabular}{ccc}
\hline $\begin{array}{c}\text { Diameter } \\
\text { kayu }\end{array}$ & $\begin{array}{c}\text { produktivitas } \\
\text { Mlesin } \\
\text { potong lama }\end{array}$ & $\begin{array}{c}\text { Mesin } \\
\text { Potong Baru }\end{array}$ \\
\hline 3 & 39.84 & 309.28 \\
5 & 36.21 & 364.96 \\
7 & 17.03 & 228.76 \\
\hline
\end{tabular}

Sumber: Hasil Observasi, 2020

Dari hasil perhitungan maka produktivitas mesin potong lama adalah sebesar $2,88 \mathrm{~cm} /$ second sedangkan produktivitas mesin baru bisa memotong $17,44 \mathrm{~cm} /$ second yang berarti produktivitas mesin baru jauh lebih tinggi dibandingkan mesin lama.

Gambaran produktivitas mesin dapat dilihat sebagai berikut:

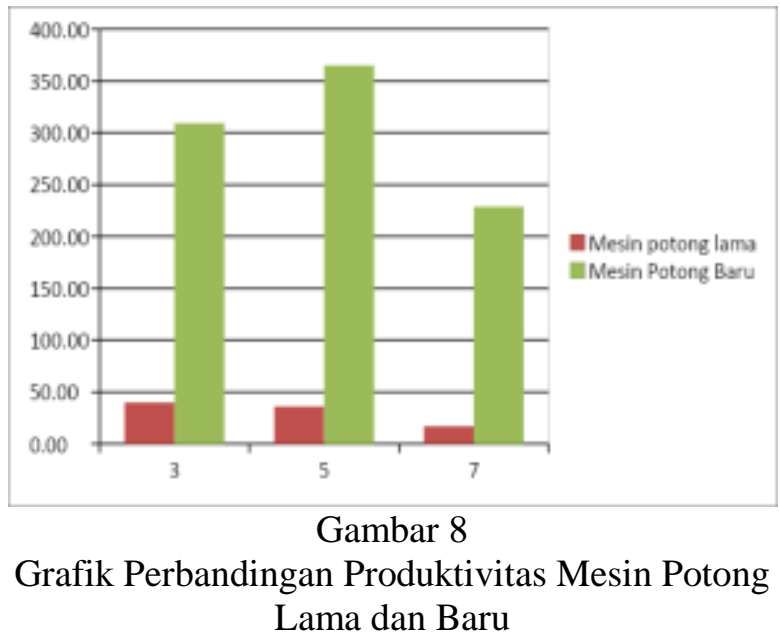

Produktivitas mesin potong baru jauh lebih tinggi dibandingkan dengan mesin potong lama sehingga pekerjaan pemotongan dapat diselesaikan dengan lebih cepat.

Peningkatan produktivitas menggunakan kompresor. Mesin kompresor dipakai tenaga untuk paku tembak. Kompresor yang lama kapasitas penyim-panan udara lebih kecil sehingga hanya bisa digunakan oleh 4 orang. Sedangkan mesin kompresor yang baru mempunyai kapasitas mesin yang lebih lama sehingga menyimpan udara dengan 
lebih banyak sehingga bisa dipakai oleh 10 orang pekerja.

\section{Peningkatan pengetahuan dan kemampuan} manajemen

Peningkatan pengetahuan adalah peningkatan pengetahuan mitra mengenai cara pemasaran yang efektif melalui aplikasi SIMBA. Di aplikasi tersebut, mitra dapat mengunggah foto produk, deskripsi dan lain sebagainya sehingga dapat memasarkan produknya dengan lebih luas. Pengetahuan manajerial juga bertambah, di mana mitra dapat belajar mengatur keuangan perusahaan melalui aplikasi sehingga dapat mengetahui laba rugi yang diperoleh dari usahanya.

\section{Peningkatan keterampilan}

Melalui aplikasi SIMBA, maka mitra dilatih untuk selalu menggunggah foto-foto produk yang diproduksi sehingga dapat melakukan aktivitas marketing dengan efektif. Mitra juga dilatih untuk terbiasa mencatat aktivitas keuangan sehingga mendapatkan laporan keuangan yang baik.

4. Peningkatan kuantitas dan kualitas produk

Peningkatan kapasitas produksi dengan penambahan mesin-mesin baru seperti mesin bor duduk, mesin potong dan mesin kompresor membuat peningkatan kuantitas dan kualitas produk.

Dari hasil observasi, peningkatan kuantitas produk merupakan peningkatan jumlah produksi per satuan produk per orang per hari yang dapat dalam dilihat pada grafik berikut:

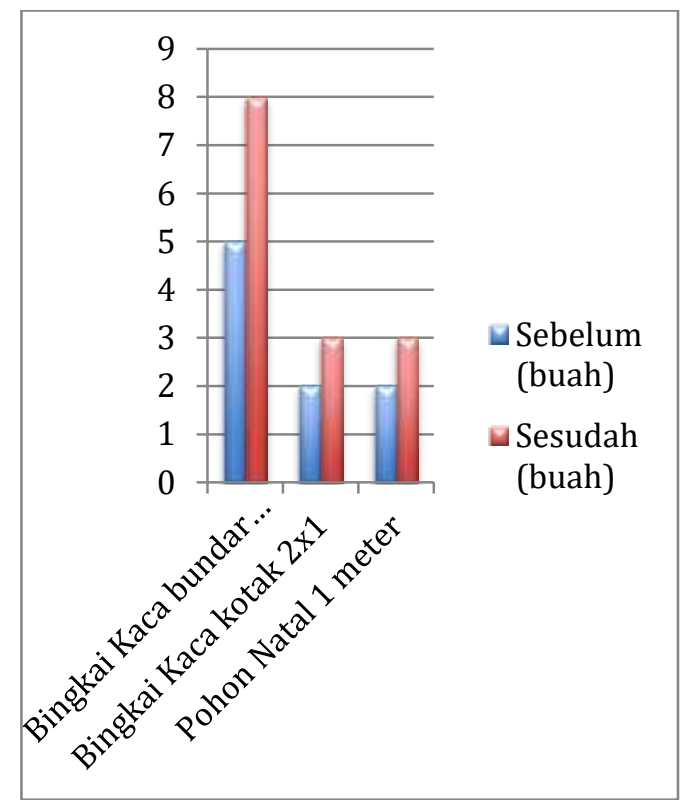

Gambar 9

Grafik Peningkatan Kuantitas Produksi
Perhitungan diatas adalah perhitungan untuk pembuatan satu jenis produk per orang per hari. Biasanya dalam pembuatan produk, maka pekerja akan bekerja dalam sistem borongan artinya perhitungan biaya tenaga kerjanya adalah per produk. Jadi pekerja bisa bekerja 6-9 jam per hari. Dari hasil observasi maka pekerja yang belum menggunakan mesin baru dapat membuat bingkai kaca bundar mencapai 5 buah/hari, sedangkan membuat bingkai kaca kotak sebanyak 2 buah/ hari dan pengerjaan pohon natal adalah sebanyak 2 buah/hari. Sesudah adanya mesin baru maka kecepatan produksi menjadi bertambah sehingga jumlah produksi produk juga meningkat. Pengerjaan bingkai kaca bundar menjadi 8 buah per hari, bingkai kotak menjadi 3 buah per hari dan pengerjaan pohon natal menjadi 3 buah per hari.

Peningkatan kualitas produk dilihat dari kerapian potongan produk dan paku yang menancap dengan baik dan tidak menonjol karena kompresor memberikan kekuatan angin yang kuat untuk menancapkan paku.

Kualitas bahan baku juga terjaga karena ada sliddning canopy, sehingga pada musim hujan saat ini katunya tidak cepat busuk sehingga kualitas dan kuantitas bahan baku terjaga dengan baik.

\section{Kesimpulan}

UKM selam ini memiliki beberapa kendala dalam menghadapi digitalisasi pada era less contact economy di masa pandemi Covid 19. Kendala itu seperti kendala produksi, pemasaran dan manajerial. Adanya program UKM indonesia Bangkit memberikan harapan bagi UKM untuk dapat meningktkan produktivitasnya dengan mengatasi kendala-kendala tersebut. Adapun solusi yang diberikan adalah sebagai berikut:

1. Peningkatan kapasitas dan produktivitas

Pemberian mesin-mesin baru seperti mesin potong, mesin bor dan mesin kompresor menyebabkan peningkatan kapasitas produksi. Produktivitas mesin potong baru jauh lebih tinggi dibandingkan dengan mesin potong lama sehingga pekerjaan pemotongan dapat diselesaikan dengan lebih cepat.

2. Peningkatan pengetahuan dan kemampuan manajemen

Peningkatan pengetahuan adalah peningkatan pengetahuan mitra mengenai cara pemasaran yang efektif, kemampuan pencatatan dan pengelolaan keuangan usaha dengan baik melalui aplikasi SIMBA.

3. Peningkatan keterampilan

Melalui aplikasi SIMBA, maka mitra dilatih untuk selalu menggunggah foto-foto produk yang diproduksi sehingga dapat melakukan 
aktivitas marketing dengan efektif. Mitra juga dilatih untuk terbiasa mencatat aktivitas keuangan sehingga mendapatkan laporan keuangan yang baik.

4. Peningkatan kuantitas dan kualitas produk

Peningkatan kapasitas produksi dengan penambahan mesin-mesin baru seperti mesin bor duduk, mesin potong dan mesin kompresor membuat peningkatan kuantitas dan kualitas produk. Kualitas bahan baku juga terjaga karena ada sliddning canopy, sehingga pada musim hujan saat ini katunya tidak cepat busuk sehingga kualitas dan kuantitas bahan baku terjaga dengan baik.

5. Manfaat sosial

Fortuna Handycraft di tengah pandemi masih bisa merekrut tenaga kerja yang saat ini kehilangan pekerjaan. Pekerja baru saat ini adalah tenaga kerja yang dahulu bekerja di industri pariwisata seperti waitress,sopir, guide dan ada juga yang bekerja di hotel.

\section{Daftar Pustaka}

Sinungan, Muchdarsyah. (2014). Produktivitas Apa dan Bagaimana. cetakan ke 9. Jakarta: Bumi Aksara.

Sutrisno, Edy. (2011). Manajemen Sumber Daya Manusia, Jakarta: Kencana.

Sutabri, T. (2014). Pengantar Teknologi Informasi. Yogyakarta. Penerbit Andi Yogyakarta.

Mulyadi. 2014. Sistem Akuntansi. Yogyakarta: Salemba Empat.

Susanto, Azhar. (2013). Sistem Informasi Akuntansi: Struktur Pengendalian Risiko Pengembangan. Edisi Perdana. Cetakan Pertama. Bandung: Lingga Jaya.

Jogiyanto, (2005). Sistem Teknologi Informasi. Yogyakarta: Andi Offset. 